\title{
Anatomical Study on Domestical Fowl (Gallus domesticus) Reproductive System
}

\author{
Estudio Anatómico del Sistema Reproductor del Gallo Doméstico (Gallus domesticus) \\ "Marilena Longo Bull; "Márcia Regina Fernandes Boaro Martins; *"Maria Dalva Cesário; \\ **** Carlos Roberto Padovani \& ${ }^{* * * * *}$ Ariel Antonio Mendes
}

BULL, M. L.; MARTINS, M. R. F. B.; CESÁRIO, M. D.; PADOVANI, C. R. \& MENDES, A. A. Anatomical study on domestical fowl (Gallus domesticus) reproductive system. Int. J. Morphol., 25(4):709-716, 2007.

SUMMARY: Lately, researchers have taken into consideration studies on birds since they represent an excellent nutritional source. There are several classical descriptions of the male reproductive tract, always aiming at establishing a correlation with shape, testicular size, age and sexual maturity. This study analyzed 50 male Gallus domesticus, 1 to 64 weeks old. The birds were collected with 10 days and then weekly until 24 weeks, following 37, 48, 59 and 64 weeks, and sacrificed by cervical displacement. It was observed the sintopies of testis with the other organs. Further, it was done the testicular measurement and then the statistical analysis by following the model of testis weight variation due to the animal age. Our results showed that the maximum weight of the right and left testes occurred with 167 and 210 days, respectively, what made us infer this species sexual maturity in this period.

\section{KEY WORDS: Anatomy; Testis; Fowl.}

\section{INTRODUCTION}

Studies on the domestic fowl sexual organs development and gonads size variation, from hatching to sexual maturity, have been of great intrest to birds raisers and scientists (Parker et al., 1942, Bennett, 1947).

Macroscopic aspects of the fowl male reproductive tract were studied by Kaupp, 1915; Gray, 1937; Parker et al.; Lake, 1957; Marvan, 1969; Lake, 1971; Tingari, 1971; Amer \& Shahin, 1975; King, 1986. Besides, studies on the birds reproductive tract, mainly concerning physiological, endocrinologic and histological aspects were carried out by Aire (1979, 1980, 1982) and Aire et al. (1979), who performed histological descriptions of the epididymal region of guinea fowl (Numida meleagris) (Aire,1979, 1980, 1982 and Aire et al.), fowl (Gallus domesticus) (Aire 1979, 1980, 1982), quail (Coturnix coturnix japonica) (Aire 1979, 1980, 1982) and duck (Anas platyrhynchos) (Aire, 1982).

There are also reports of works on domestic fowl (Gallus domesticus) testis albunigeous tunic (Aire,1979), seminiferous tubules (Marvan), testicular net (Aire, 1982 and
Tingari), ductus deferens and epididymis (Marvan; Tingari; Tingari \& Lake, 1972 and Aire, 1980), cloaca (Marvan) and interstitial tissue (Amer \& Shahin and Rothwell,1975).

Besides these species, Mercadante et al. (1983) carried out analysis of the anatomical features of male pigeon (Columbia livia, L.) testis, epididymis, ductus deferens and copulator organ.

With special reference to the male reproductive tract organs vascularization, we have found reports on birds (Gallus gallus) (Dias et al., 1980, 1981) and Gallus domesticus (Nishida, 1964), being found for Gallus domesticus studies on testicular weight and dimensions Marvan and Amer \& Shahin. Also, Lake (1971), states that birds do not have a pampiniform plexus typical of mammals.

Until the 50's, few studies reported results correlating the testis growth with body weigh (Kumaran \& Turner, 1949), however, Marvan and Amer \& Shahin, carried out studies on fowl (Gallus domesticus) weight and testis dimensions.

* Departamento de Anatomia, IB, Universidade Estadual Paulista - Botucatu SP (UNESP), Brasil

** Departamento de Morfologia, IB, Universidade Estadual Paulista - Botucatu / SP (UNESP), Brasil

**** Departamento de Bioestatística, IB, Universidade Estadual Paulista - Botucatu / SP (UNESP), Brasil

*****Departamento de Produção Animal, FMVZ, Universidade Estadual Paulista - Botucatu / SP (UNESP), Brasil 
Marvan, Tingari, Amer \& Shahin and Aire (1979, 1980, 1982), tried to establish the fowl (Gallus domesticus) sexual maturity, correlating testicular development with testicular weight and the animals age.

Aiming at establish the annual testicular cycle of quail (Coturnix coturnix japonica), Artoni (1993), described its testicular microscopy and morphometry.

Hess et al. (1976) described the ductus sucession from the seminiferous tubules to the ductus deferens papilla, as well the microscopy of the epididymal region and ductus deferens in turkey (Meleagris gallopavo). On the other hand, Reviers (1971), by studying the testis development of hybrid Rhode $\mathrm{x}$ Wyandotte, reported the testis ponderal growth by using the organ weight and histological analysis through seminiferous tubules diameter measures. Similarly, Vehrencamp (1982) in studies with weighing and measures of ani (Crotophaga sulcirostris) testis, carried out measurements of seminiferous tubules diameters, correlating them according to age.

In studies on testicular development, the authors approached only immature animals or until the sexual maturation age or sexually mature animals (Marvan; Tingari; Amer \& Shahin and Aire, 1979, 1980, 1982).

Based on this literature, we proposed to observe the macroscopy of the male reproductive tract organs, as well analyze and describe the testicular development related with the organ weight and dimensions, and infer the sexual maturity age with basis on testis macroscopic data.

\section{MATERIAL AND METHOD}

We analyzed 50 male animals from Granja Big Birds, in Tatui city, São Paulo State, where they were kept under light and feeding conditions adopted by it.

The samples of 2 animals were slaughtered initially with 10 days and then, weekly, until 24 weeks. Further with $37,48,59$ and 64 weeks, that is, 9, 11, 14 and 15 months, respectively.

The animals were weighed and sacrificed by cervical displacement. After abdominal laparotomy, the visceras were carefully handled for the reproductive organs approach, allowing the study of the testis general morphology and topographical relations.
The parts were schematized and photographed, then the organs were removed and the gonads dissected under estereoscopic microscope.

The testis macroscopic structure was analyzed "in situ", taking into consideration the following parameters: dimensions (length and width), shape, position asymetry, holotopy and sintopy. The testis were removed and weighed in analytical scale.

For the statistical procedures of the observed data, it was considered the adjustment of polynomial regression of the testis length, width and weight in function of the animals age, in days, indicating as reply model the significant adherence polynomial $(\mathrm{P}<0,05)$, where the highest determination coefficient was obtained. From the established model and by derivation, its respective models of variation rates were obtained (Draper \& Smith, 1998).

\section{RESULTS}

The testes are even organs, internal, parallel, displaced at the sides of the body median line, presenting rounded surface, however, with varied shape. Until the $20^{\text {th }}$ week, they were oval, elongated, curve, tortuous and, sometimes, with fine caudal extremity (Fig.1), showing from the $21^{\text {st }}$ week a high increase in size and oval shape (Fig. 2A).

The testis presented a central area slightly depressed through which the testicular arteries from the abdominal aorta artery supply them (Fig. 2B); being fixed to the body dorsal wall by meso extensions, permitting a certain buoyancy, reminding that the adjacent organs contribute to their position maintenance.

Comparative analysis of the right and left testis length showed that up to 24 weeks of age the left testis had higher length, in most cases (Fig. 3A, B and C); however, in less proportion, the right testis is longer than the left, or even equal. Yet, at advanced ages, the right testis length was predominant (Fig. 3D).

The testis were displaced caudally to the lungs and ventrally to the right and left kidneys and keep relation to the right and left hepatic lobes visceral face, respectively. Until the age of 20 weeks, they were displaced over the kidneys cranial portion (Fig. 3A and B), grow markedly from the $21^{\text {st }}$ week and at the $23^{\text {rd }}$ week they overlay to the kidneys medial portion (Fig. 3C and D). 

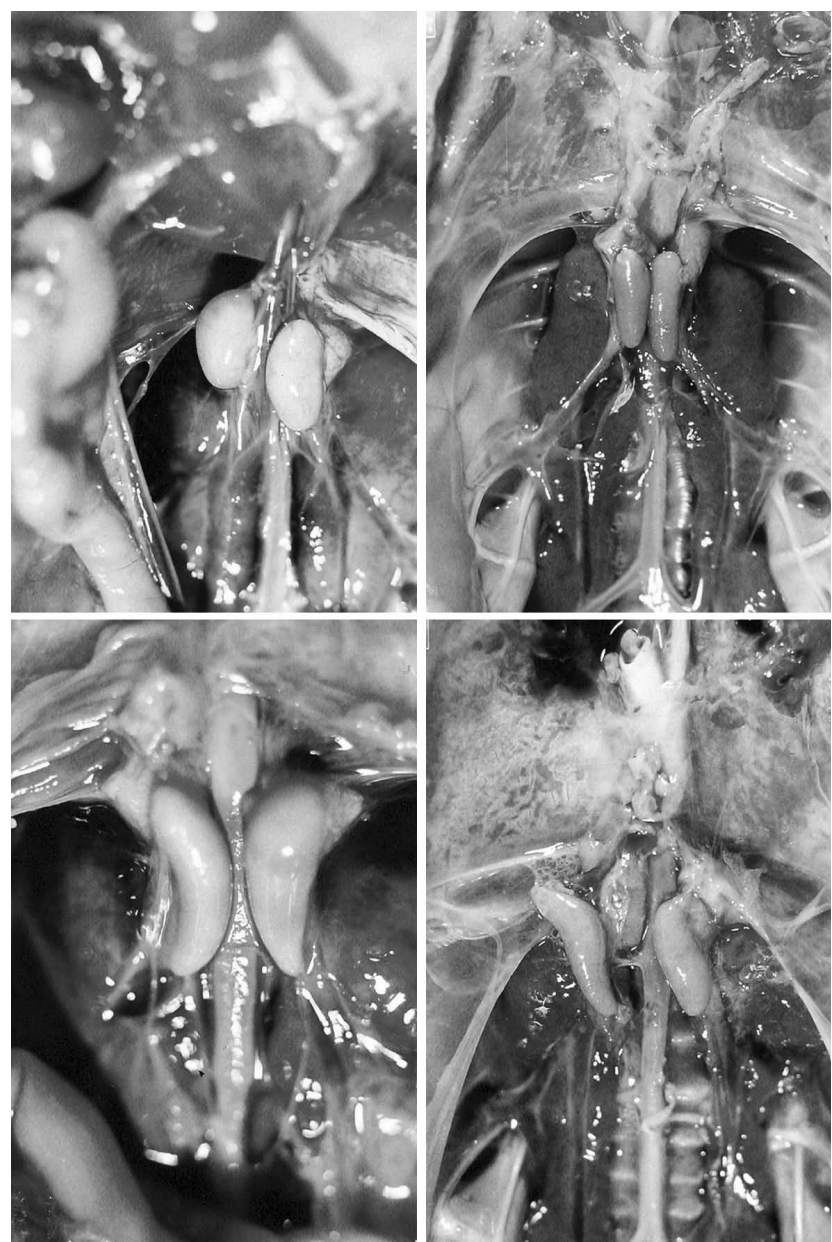

Fig. 1. Domestic fowl testis (T) up to 20 weeks of age with shapes: A) oval; B) elongated; C) curve; D) tortuous.
Thus, up to 21 weeks of age, we noticed that the spleen occupies a ventral position in relation to the left testis, while the aglandular stomach is lateral to it. However, between 22 and 59 weeks, the spleen begins occupying the medial position and the aglandular stomach is ventrally to the left testis (Fig. 4A).

With the testis length growth, the jejunum, which had relation with the right testis cranial pole, begins to maintain close relation to its caudal pole (Fig. 4B and C).

The extratesticular seminiferous path is made up bilaterally of the epididymis and ductus deferens. The epididymis are firmly applied to the corresponding testis dorsomedial face and continue with the ductus deferens, which are located at the sides of the body median line medially to the ureters (Fig. 2B). Distally, the ductus deferens are lateral to the ureters to open themselves through the ductus deferens papilla in the urodeo, median segment of the cloaca, followed by the proctodeo, last segment of the cloaca, on whose ventral floor is the phallus, the male copulator organ (Fig. 5D).

When resting, the cloaca dorsal and ventral labiuns are rolled up, seem to be the cloaca opening in form of a transverse fissure (Fig. 5A). However, when the labiuns evert, we observed that the opening may be a vertical fissure (Fig. 5C), or a rounded opening interrupted by a ventral face groove, where the copulator organ is internally found (Fig. 5B). It is compounded by the median phallic body or
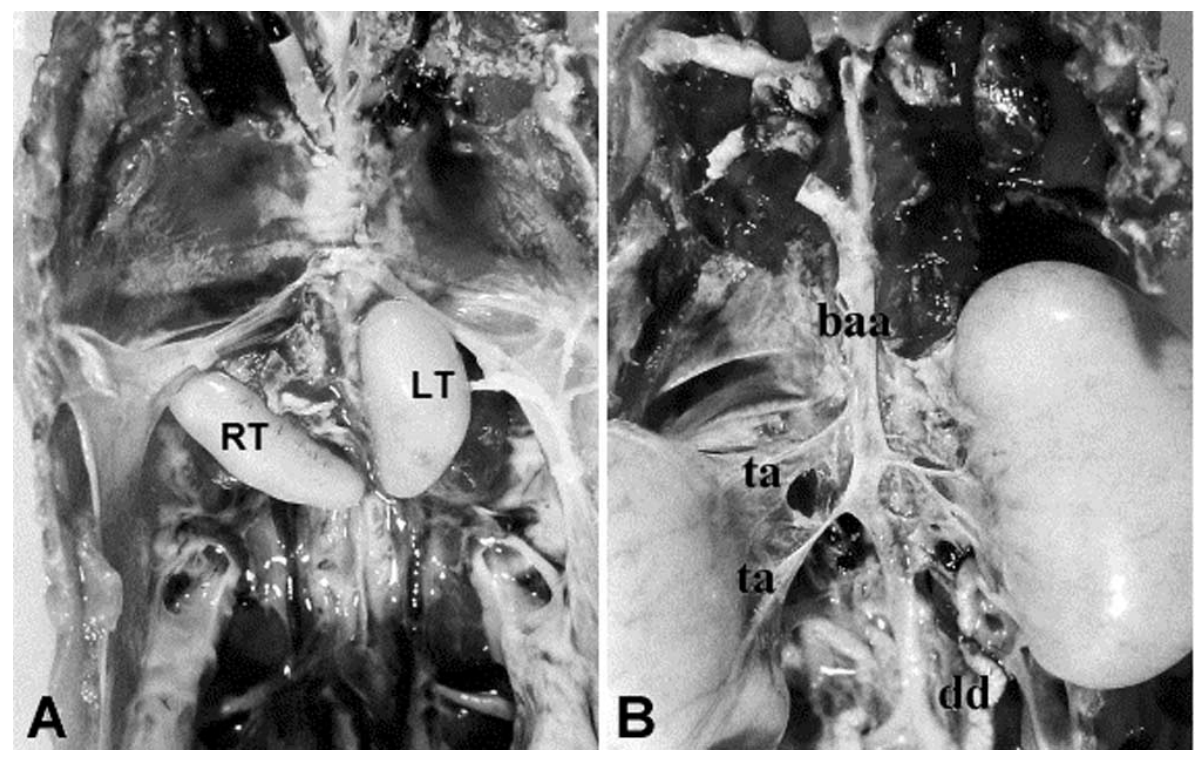

Fig. 2A) Fowl testis (T) 21 weeks of age. B) Observe: testicular arteries (ta); abdominal aorta artery (baa) and ductus deferens (dd). 


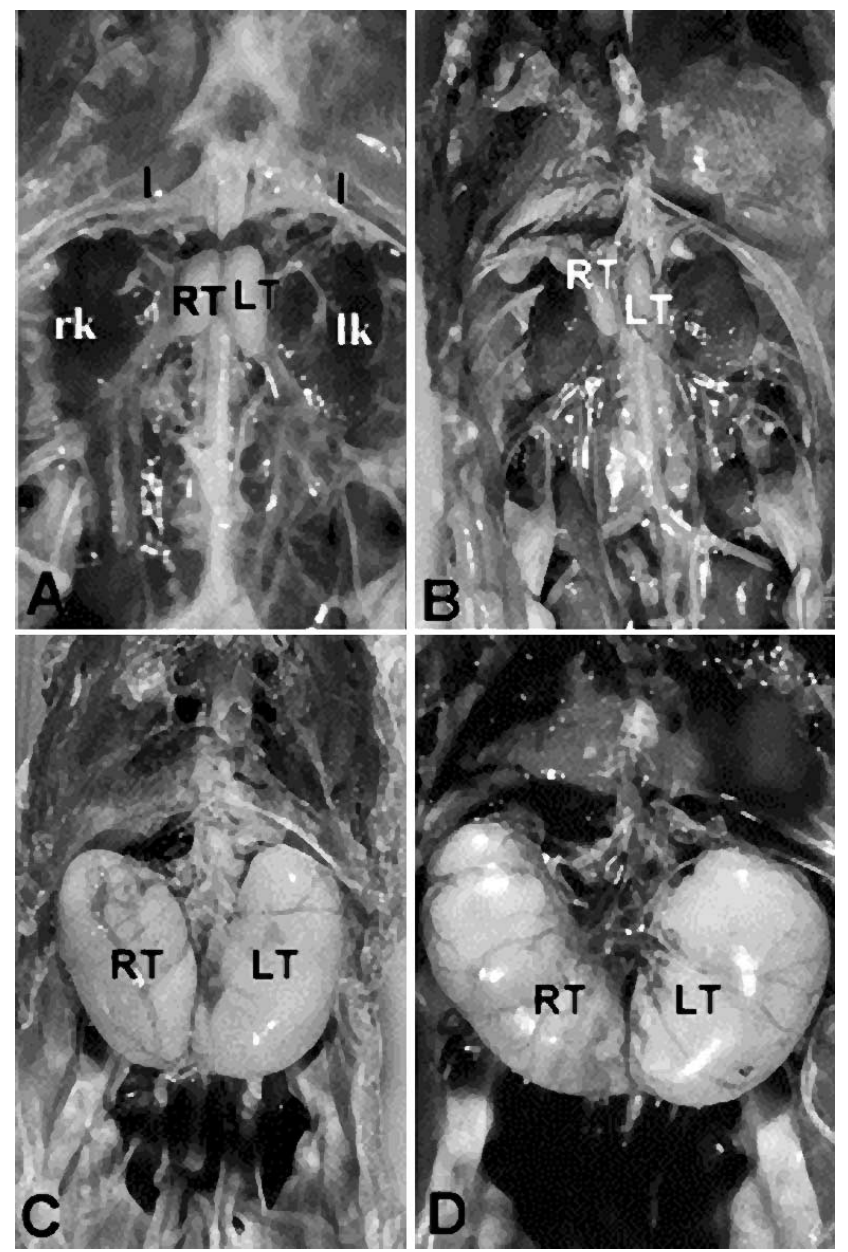

white body (Fig. 5E) and the lateral phallic bodies, which were observed along with the lymphatic pleats and the uroproctodeal pleat in the animal in erection (Fig. 5F).

The growth variation model allowed us to verify when the testis reached their maximum growth, until what age they presented growth and the beginning of the decrease. For the weight, we noticed that the right testis reached its maximum growth at 167 days, more precocious than the left one, with 210 days. Weight decrease began at 351 days for the right testis and 415 days for the left testis. We observed that the length of both testis presented maximum expression at 167 days and the beginning of decrease occurred at 359 days for the right testis and 353 days for the left one. As for width, the maximum growth of the left side was precocious at 157 days in relation to the right with 217 days, presenting decrease from 370 and 441 days, respectively (Table I and Fig. 6).

Fig. 3. Fowl testis with: A) 13 weeks of age. Left testis (LT), longer than the right testis (RT); B) 20 weeks of age: right testis (RT) longer than the left testis (LT); C) 23 weeks of age: right testis (RT) with the same lenght of the left testis (LT); D) 59 weeks of age. Right testis (RT) with lenght higher than the left testis (LT); lung (l); right kidney (rk); left kidney (lk).
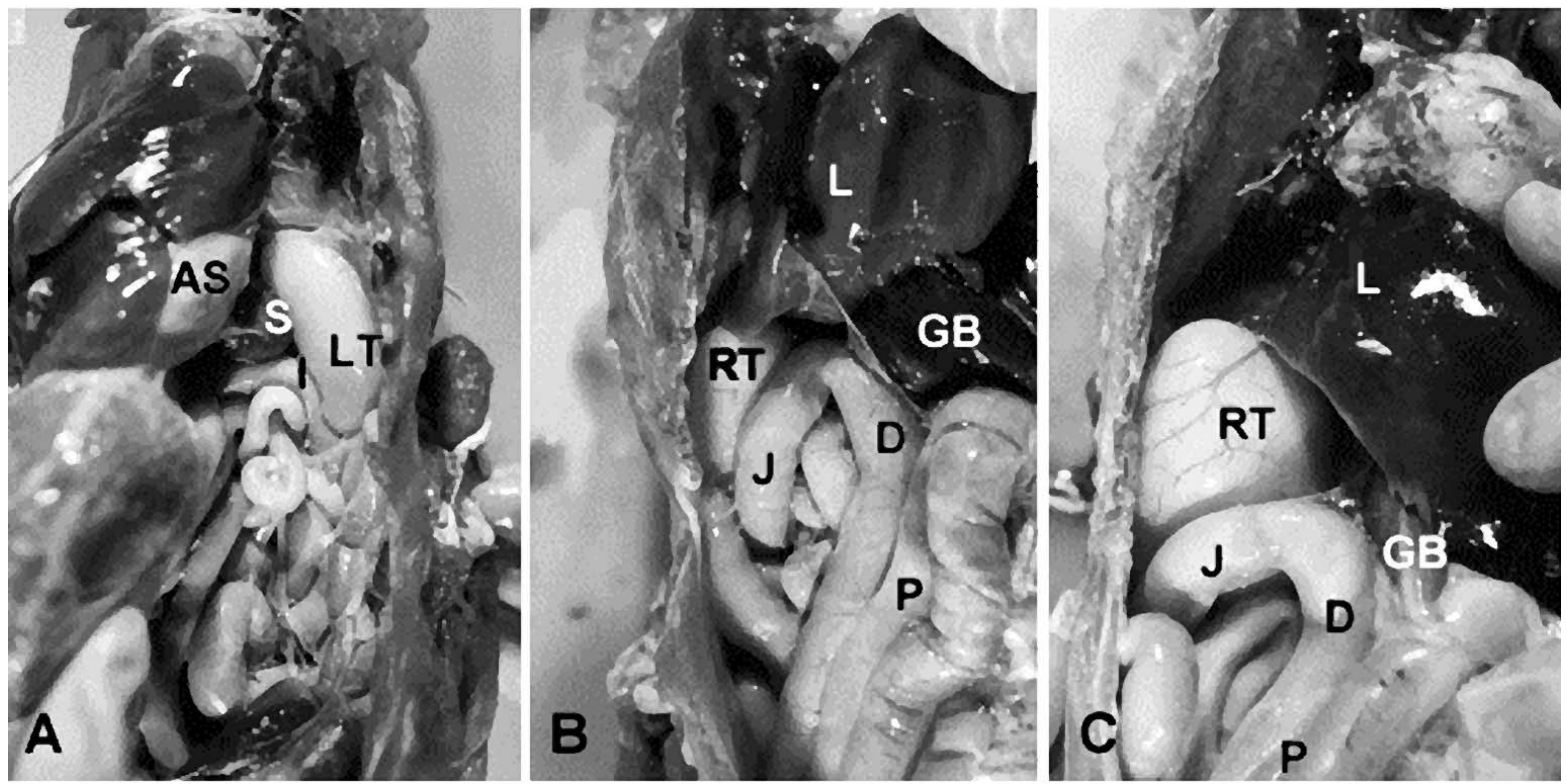

Fig. 4 A) Abdominal cavity of 22-week old fowl: left testis (LT), spleen (S), aglandular stomach (AS), ileum ( I ). B) and C)right testis (RT); liver (L); gall bladder (GB); duodenum (D); jejunum (J); pancreas (P). 

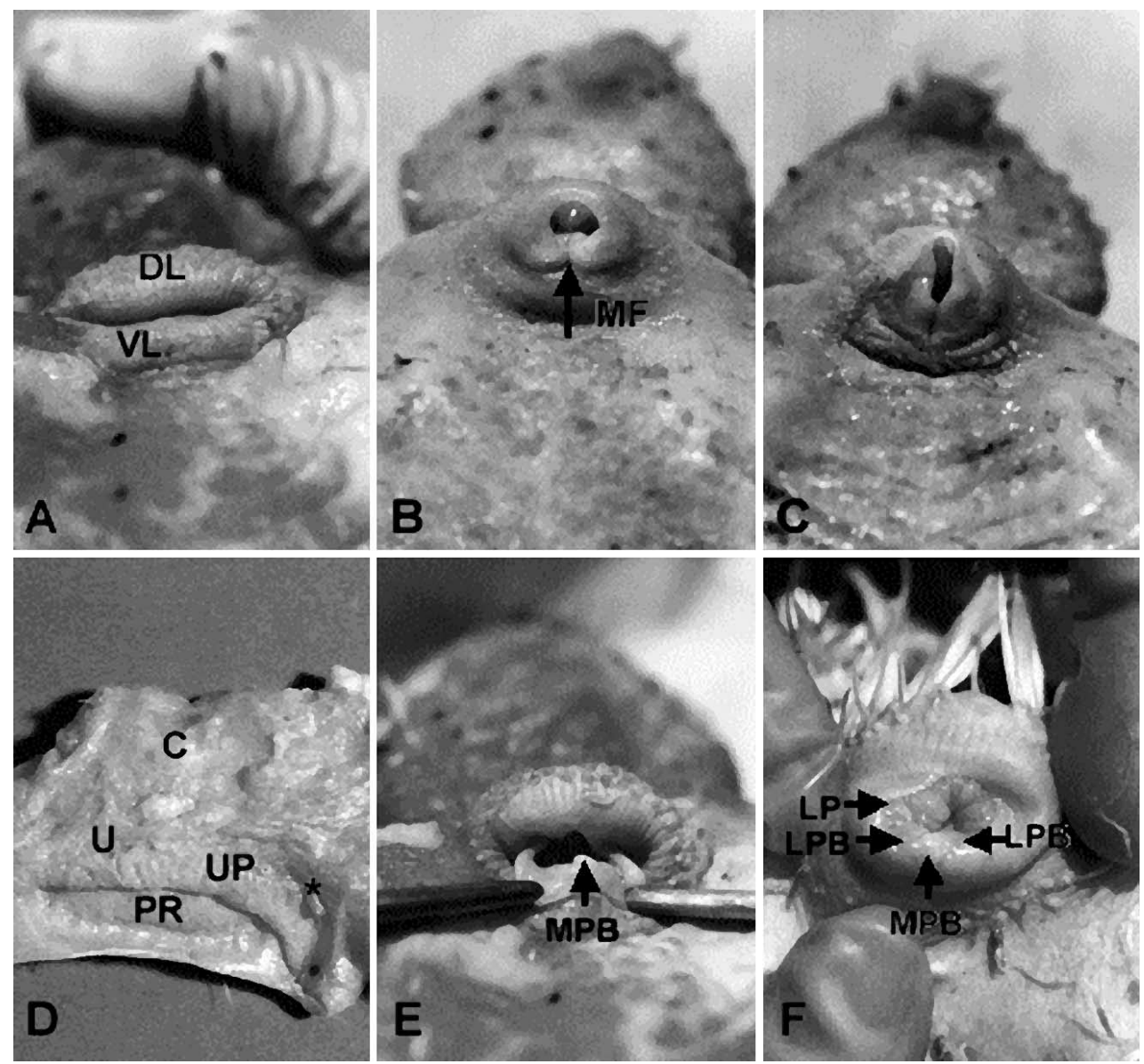

Fig. 5. Cloaca of adult fowl at rest: A) opening in transverse fissure: dorsal labium (DL), ventral labium (VL); B) round opening: median furrow (MF); C) opening in vertical fissure and everted labium; D) distal portion of adult fowl showing: coprodeo (C ); urodeo (U); proctodeo (PR); uroproctodeal pleat (UP); ductus deferens papilla (*); E) copulator organ: median phallic body (MPB). F) fowl copulator organ in erection: median phallic body (MPB); lateral phallic bodies (LPB); lymphatic pleats (LP).

Table I. Testis growtl regression model due to age and respective growth variation models.

\begin{tabular}{|c|c|c|c|}
\hline Variable & Testis & Regression Model & $\begin{array}{c}\text { Determination } \\
\text { Coefficient }(\%)\end{array}$ \\
\hline \multirow[t]{2}{*}{ Length } & Right & $\mathrm{RL}=4.27266+0.05681 \mathbf{I}+0.00105 \mathbf{I}^{2}-0.0000021 \mathbf{I}^{3}$ & 81.15 \\
\hline & Left & $\mathrm{LL}=1.16020+0.02075 \mathbf{I}+0.00050 \mathbf{I}^{2}-0.0000010 \mathbf{I}^{3}$ & 77.54 \\
\hline \multirow[t]{2}{*}{ Width } & Right & $\mathrm{RWi}=-1.33646+0.00567 \mathbf{I}+0.00039 \mathbf{I}^{2}-0.0000006 \mathbf{I}^{3}$ & 72.12 \\
\hline & Left & $\mathrm{LWi}=4.89381+0.08564 \mathbf{I}+0.00066 \mathbf{I}^{2}-0.0000014 \mathbf{I}^{3}$ & 76.72 \\
\hline \multirow[t]{2}{*}{ Weight } & Right & $\mathrm{RWe}=0.80388+0.02195 \mathbf{I}+0.00060 \mathbf{I}^{2}-0.0000012 \mathbf{I}^{3}$ & 78.36 \\
\hline & Left & Lwe $=-1.02503-0.00349 \mathbf{I}+0.00044 \mathbf{I}^{2}-0.0000007 \mathbf{I}^{3}$ & 72.91 \\
\hline \multirow[t]{2}{*}{ Length } & Right & $\mathrm{dRL} / \mathrm{dI}=0.05681+0.00210 \mathrm{I}-0.0000063 \mathbf{I}^{2}$ & 166.67 days \\
\hline & Left & $\mathrm{dLL} / \mathrm{d} \mathrm{I}=0.02075+0.00100 \mathbf{I}-0.0000030 \mathbf{I}^{2}$ & 166.67 days \\
\hline \multirow[t]{2}{*}{ Width } & Right & $\mathrm{dRWi} / \mathrm{dI}=0.00567+0.00078 \mathbf{I}-0.0000018 \mathbf{I}^{2}$ & 216.67 days \\
\hline & Left & $\mathrm{dLWi} / \mathrm{d} \mathrm{I}=0.08564+0.00132 \mathrm{I}-0.0000042 \mathbf{I}^{2}$ & 157.14 days \\
\hline \multirow[t]{2}{*}{ Weight } & Right & $\mathrm{dRWe} / \mathrm{d} \mathrm{I}=0.02195+0.00120 \mathrm{I}-0.0000036 \mathbf{I}^{2}$ & 166.67 days \\
\hline & Left & $\mathrm{dLWe} / \mathrm{dI}=-0.00349+0.00088 \mathrm{I}-0.0000021 \mathbf{I}^{2}$ & 209.52 days \\
\hline
\end{tabular}




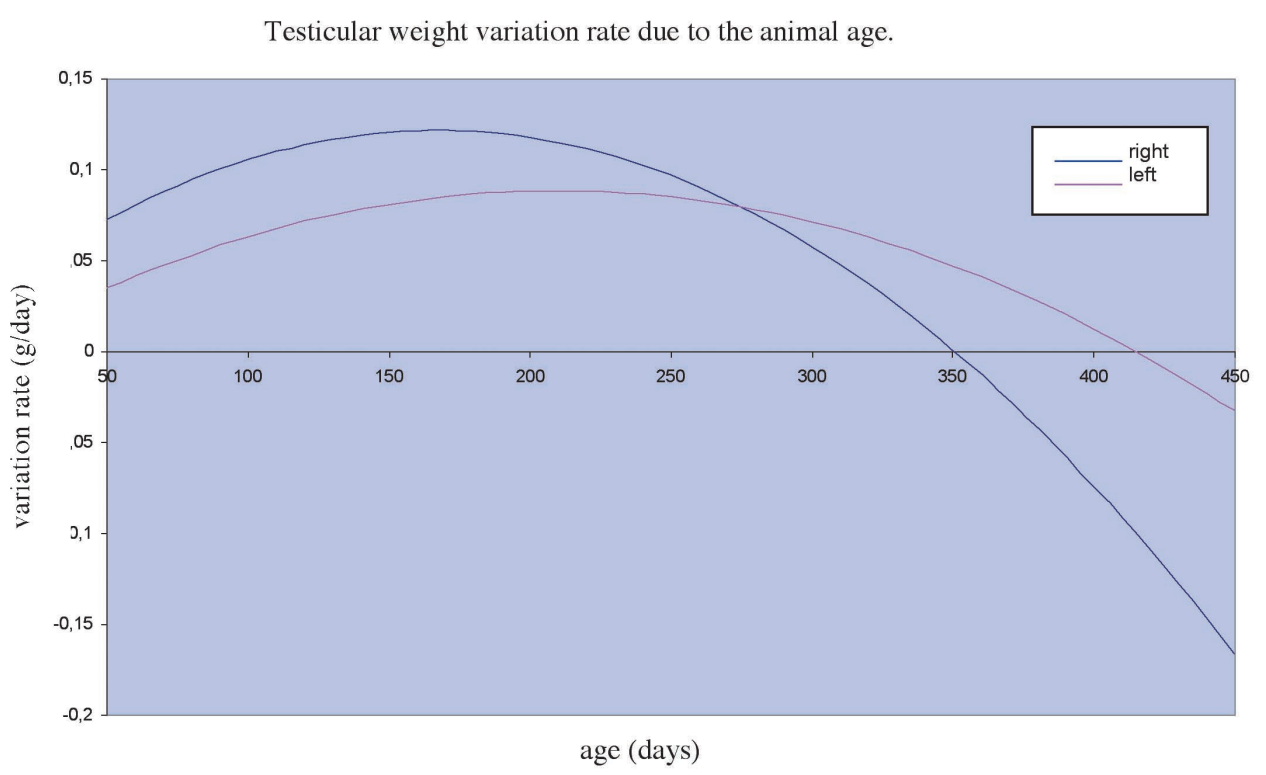

where several small testicular arteries reach the testis.

Concerning sintopy, our results agree with those by Lake (1957) and Mercadante et al., who describe the testis caudally to the lungs, along the kidneys cranial extremity. Yet, in our results, we observed that up to the $20^{\text {th }}$ week they were placed on the kidneys cranial portion and grew markedly from the $21^{\text {st }}$ week, reaching the kidneys median portion.

Fig. 6. Testicular weight variation rate due to the animal age.

\section{DISCUSSION}

Classical descriptions of male reproductive tract localization in domestic birds (Gray; Getty, 1986; King \& McLelland, 1981; Artoni; Büll, 1994, Dyce et al., 1996) are similar to those verified by us.

Studies by Amer \& Shahin with fowls report that at 1 month of age the testis are elongated and cylindric; at 2 months of age, the left testis assumed the shape of a bean, while the right testis remained elongated, and then, at 4 months, both testis were bean shaped.

On the other hand, Artoni described that the right testis of adult quail tends to be a little longer and thick than the left one, which is more rounded, shorter and wider. Yet, in Columbia Livia, L. it is reported a bean shape for the left testis and ovaled for the right one, when isolated (Mercadante et al.).

Such data are different from those found by us, where it was noticed a great variation in the fowl testis form until the $20^{\text {th }}$ week, age from which a definitive and oval shape was assumed.

Similarly to Gray, Mercadante et al. and Artoni, we could observe in the fowl testis the presence of a testicular hilum in the medial edge. However, the last two authors refer just to the presence of a testicular artery for testis irrigation, while our results corroborate with those by Gray,
Although Gray refers to the testis as retroperitoneal organs, Amer \& Shahin; Lake (1971) and Mercadante et al. refer to the presence of a mesorchium, fixing the testis to the abdomen dorsal wall, which was also observed by us.

According to Latimer (1924) and Artoni, the testis weight varied with basis on an annual testicular cycle. Maybe comparatively, Kaupp reports that males become sexually active when the testis reach their maximum size. Such data corroborate with ours, where the maximum weight of the right and left testis occurred at 167 and 210 days, respectively, suggesting sexual maturity in this species.

Lineage seems to be a preponderant factor to influence the sexual maturity time (Lake, 1971; Hogue \& Schnetzler, 1937). Besides, correlate studies establish comparative parameters of age, testicular weight and lineage (Parker et al.; Munro et al., 1943; Bennett).

Several works agree with our results as for the epididymis size and position and the ductus deferens site and tortuousity (Kaupp; Lake, 1957; Amer \& Shahin; Tingari, Mercadante et al. and Artoni).

The ductus deferens descending course parallel to the ureter in direction to the urodeo is similar in fowl (Lake, 1957; King), male pigeon (Mercadante et al.), and it was confirmed in this study.

Similarly to Mercadante et al. and Lake (1957), we noticed that the ductus deferens distal extremity opens in the urodeo through the ductus deferens papilla. 
BULL, M. L.; MARTinS, M. R. F. B.; CESÁRIO, M. D.; PADOVANI, C. R. \& MENDES, A. A. Estudio anatómico del sistema reproductor del gallo doméstico (Gallus domesticus) reproductive system. Int. J. Morphol., 25(4):709-716, 2007.

RESUMEN: Últimamente, los investigadores han tomado en consideración estudiar aves, ya que estas representan un importante recurso nutricional. Existen varias descripciones clásicas del tracto reproductor de ellas, las cuales apuntan a establecer una correlación entre la forma, tamaño testicular, edad y madurez sexual. Este estudio analizó 50 Gallus domesticus machos, entre la semana 1 a 64 de edad. Las aves se recolectaron a los 10 días y semanalmente hasta la semana 24, luego de las semanas 37, 48, 59 y luego sacrificadas por desplazamiento cervical. Se observó la sintopía de los testículos con los otros órganos. Además, se realizaron la medición de los testículos y el análisis estadístico, seguido del modelo de variación de peso testicular en relación a la edad del animal. Nuestros resultados muestran que el peso máximo de los testículos, derecho e izquierdo, ocurre en los días 167 y 210 , respectivamente, lo que nos hace inferir que la madurez sexual ocurre en ese periodo.

PALABRAS CLAVE: Anatomía; Testículos; Gallo.

\section{REFERENCES}

Aire, T. A. Micro-stereological study of the avian epididymal region. J. Anat., 129(4):703-6, 1979.

Aire, T. A. The ductuli efferents of the epididymal region of birds. J. Anat., 130(4):707-23, 1980.

Aire, T. A. The rete testis of birds. J. Anat., 135(1):97-100, 1982.

Aire, T. A.; Ayeni, J. S. \& Olowo-Okorun, M.O. The structure of the excurrent ducts of the testis of the guinea-fowl (Numida meleagnis). J. Anat., 129(3):633-43, 1979.

Amer, F. I. \& Shahin, M.A. The post-hatching development of the gonads in the fowl, Gallus domesticus. Ann. Zool., 11(1):1-25, 1975.

Artoni, S. M. B. Consideraçôes sobre a morfologia e a histofisiologia do testiculo da codorna (Coturnix cournix japonica). Botucatu-São Paulo, 1993. Tese (Doutorado em Anatomia) - Instituto de Biociências, Universidade Estadual Paulista.

Bennett, C. H. Relation between size and age of the gonads in the fowl from hatching date to sexual maturity. Poult. Sci., 26:99-104, 1947.

Büll, M. L. Anatomia do aparelho reprodutor do macho e da fêmea. In: Fisiologia da reprodução de aves. Campinas. Fundação APINCO de Ciência e Tecnologia Avícolas, 1994.

Dias, S. M.; Silva, P. P.; Oliveira, M. C. \& Orsi, A. M. Distribuição arterial em gônada de ave (Gallus gallus, Indian River). Acta Biol. Leopoldensia, 2(1):75-81, 1980.
Dias, S. M.; Silva, P. P.; Orsi, A. M.; Oliveira, M. C. \& Silva, Z. Massa de Schlesinger e angioarquitetura do testículo de Gallus gallus - Indian River. Rev. Fac. Med. vet. Zootec., Univ. São Paulo, 18(2):93-5, 1981.

Draper, N. R. \& Smith, H. Applied regression analysis. $3^{\text {rd }}$ ed. John Wiley, New York, 736, 1998.

Dyce, J. M.; Sack, W. O. \& Wensing, C. I. G. Anatomia das aves. In: Tratado de anatomia veterinária. Rio de Janeiro: Guanabara Koogan, 1996. pp. 631-50.

Getty, R. Sisson and Grossman's. The anatomy of the domestic animals. Philadelphia, Saunders Company, 1986.

Gray, J. C. The anatomy of the male genital ducts in the fow. J. Morphol. 60:393-405, 1937.

Hess, R.A.; Thurston, R. J. \& Biellier, H.V. Morphology of the epididymal region and ductus deferens of the turkey (Meleagris gallopavo). J. Anat., 122(2):241-52, 1976.

Hogue, R. L. \& Schnetzler, E. E. development of fertility in young Barred Rock males. Pout. Sci., 16:62-7, 1937.

Kaupp, B.F. Male reproductive organs of birds. Am. J. Vet. Med., 10:461-4, 1915.

King, A. S. \& McLelland, J. Form and function in birds. London, Academic Press, 1981.

King, A. S. Aparelho urogenital das aves. In: Getty, R. Sisson and Grossman's. Anatomia dos animais domésticos. $5^{\mathrm{a}}$ ed. Rio de Janeiro, Interamericana, 1986. V. 2, pp.1805-13. 
Kumaran, J. D. S. \& Turner, C.W. The normal development of the testes in the white Phymouth Rock. Poutry Sci., 28:511-20, 1949 .

Lake, P. E. The male in reproduction. In: Bell, D. J.; Freeman, B. M. Phisiology and Biochemistry of the Fowl. New York, Academic Press, 1971. V. 3. pp.141147.

Lake, P. E. The male reproductive tract of the fowl. J. Anat., 91:16-29, 1957.

Latimer, H. B. Postnatal growth of the body, systems, and organs of the Single-Comb White Leghorn chicken. J. Agr. Research., 29:363-97, 1924.

Marvan, F. Postnatal development of the male genital tract of the Gallus domesticus. Anat. Anz. Bd., 124:443-62, 1969.

Mercadante, M. C. S.; Orsi, A. M.; Vicentini, C. A.; Valente, M. M. \& Dias, S. M. Observações anatômicas sobre o trato reprodutor masculino do pombo (Columba livia, L.). Rev. Cien. biomed., São Paulo, 4:37-44, 1983.

Munro, S. S.; Kosin, I. L. \& Macartney, E. L. Quantitative genic-hormone interations in the fowl: I. Relative sensibility of five breeds to an anterior pituitary exytract prossessing both thyrotropic and gonadotropic properties. Am. Nat., 77:256-73, 1943.

Nishida, T. Comparative and topographical anatomy of the fowl. XLII Blood vascular system of the male reproductive organs. Japan. J. Vet. Science, 26(4):211$29,1964$.

Parker, J. E.; McKenzie, F. F. \& Kempster, H.L. Development of the testes and combs of White Leghorn and New Hampshire cockerels. Poultry Sci., 21:35-44, 1942.

Reviers, M. Le développement testiculaire chez le coq. ICroissance ponderale des testicules et développement des tubes séminifères. Ann. biol. anim. Bioch. Biophys., 11(4): 519-30, 1971.

Rothwell, B. Designation of the cellular component of the peritubular boundary tissue of the seminiferous tubule in the testis of the fowl (Gallus domesticus). Br. Poult. Sci.16: 527-9, 1975.

Tingari, M. D. On the structure of the epididymal region and ductus deferens of the domestic fowl (Gallus domesticus). J. Anat., 109(3):423-35, 1971.
Tingari, M. D. \& Lake, P. E. Ultraestrutural evidence for resorption of spermatozoa and testicular fluid in the excurrent ducts of the testis of the domestic fowl (Gallus domesticus). J. Reprod. Fert., 31:373-81, 1972.

Vehrencamp, S. L. Testicular regression in relation to incubation effort in a tropical cuckoo. Hormones and Behavior, 16:113-20, 1982.

Correspondence to:

Prof. Dra. Marilena Longo Bull

Departamento de Anatomia

Instituto de Biociências - UNESP

CEP 18618-000

Botucatu, SP

BRASIL

Email:marilena@ibb.unesp.br

Received: 14-05-2007

Accepted: 24-08-2007 